\title{
Cervico-Brachio-Thoraco-Abdominal Necrotizing Fasciitis of Dental Origin: A Clinical Case
}

\author{
Koffi KM ${ }^{1 *}$, Ory DMAO ${ }^{2}$, Ouattara $\mathrm{B}^{1}$, Harding-Kaba $\mathrm{MB}^{1}$, Moudalbaye $\mathrm{NS}^{1}$, Daweni $\mathrm{D}^{1}$, \\ Bouletreau $\mathbf{P}^{3}$ \\ ${ }^{I}$ Department of stomatology, maxillo-facial and plastic surgery of the face CHU Cocody (RCI), Côte d'Ivoire \\ ${ }^{2}$ Department of stomatology, maxillo-facial and plastic surgery of the Face CHU Bouaké (RCI), Côte d'Ivoire \\ ${ }^{3}$ Department of stomatology, maxillo-facial, plastic and the face surgery CHU-Lyon Sud (France), France
}

*Corresponding Author: Dr KOFFI Konan Marc, Department of stomatology, maxillo-facial and plastic surgery of the face CHUCocody (RCI), Côte d'Ivoire, Email: marckoffi@ ymail.com

\begin{abstract}
The Necrotizing fasciitis (NF) or "flesh-eating disease" is a rare polymicrobial infection caused by "flesh-eating" germs. It is a medical-surgical emergency with a high lethality. In the absence of pathognomonic sign, its clinical diagnosis is difficult. Medical imaging (computed tomography and magnetic resonance imaging) is of great value in the diagnosis. The diagnostic certainty is given by the exploratory incisions and histology of the biopsy piece. Surgery is the basic treatment associated with antibiotic therapy, the VAC therapy and hyperbaric oxygen therapy.
\end{abstract}

We report the case of a 43 years old patient who showed a cervico-brachio-thoraco-abdominal necrotizing fasciitis of dental origin (dental abscess of 36) with a notion of nonsteroidal anti-inflammatory drug taking in monotherapy. The development after extensive surgical excision associated with antibiotic therapy directed to natural honey was favorable.

The authors through this clinical case do a review of the literature on this pathology.

Keywords: Necrotizing fasciitis- Dental abscess -cervico-facial cellulitis

\section{INTRODUCTION}

The term Necrotizing fasciitis (NF) was initially used by Wilson in 1952 [1].Historically this disease was described at the end of the 18th century by Claude Pouteau in 1783. The infection was more common in military hospitals and known under the name of "hospital gangrene" or "phadegenagan graenosa". Civilians were less affected and this disease appeared to be confined toprostitutes' environment where the disease was aggressive and involved in the ravages to the vaginal, perineal and anus area [2-3-4]. It is a necrotizing bacterial dermo-hypodermitis with superficial aponeurosis infection of the muscles. It is caused by a contamination by germs known as "flesh eaters» with high toxinogenicity power represented mostly by the group A betahemolytic streptococcus. It is a therapeutic medical-surgical emergency with mortality figures from $30-76 \%$ [5-6]. In the absence of pathognomonic sign at the beginning, theNF may be difficult to differentiate from the cellulitis and other superficial skin infections. Studies showed that only15-34\% of NF have an accurate diagnosis. These patients are sometimes treated for simple cellulitis until their state rapidly get worse [7].

We report a case of necrotizing fasciitis at the cervico-brachio-thoraco-abdominal localization in a 43-year-old patient with a dental abscess on a right lower molar. We also discuss the epidemiological presentation, and the multi disciplinary management of these NF.

\section{OBSERVATION}

A 43-year-old patient came in our department for a left cervico-facial swelling. The signs might have begun 3 weeks before his admission by an odontalgia on a decayed tooth of the left molar group (36). Niflumic acid auto medication ( 2 capsules twice daily) might have been undertaken. This was followed by a left genial swelling that gradually increased in volume to extend secondary to the anterior cervical region, 
all growing in a painful context. The medical and surgical background of the patient were without particularity.

The clinical examination carried out at the entrance revealed: a conscious adynamic patient, a $\mathrm{BP}$ at $110 / 70 \mathrm{mmHg}$, a temperature at 37.5.Inexobuccal we noted, a cervico-facial swelling covered with a tight shiny Painful warmskin not forming body with the bone and with zones of fluctuations whereas in endobuccal there was a limitation of the mouth opening to $15 \mathrm{~mm}$, poor oral hygiene, a fistulisation at the collar of 36 leaving solder franc pus And a decayed tooth of 36 . The blood count showed a leukocytosis at 29,000 GB and an anemia at $7 \mathrm{~g} / \mathrm{dl} \mathrm{Hb}$.In front of this table we evoked the diagnosis of a cellulitis diffused in suppuration phase of dental origin (36). After pus removal for bacteriological examination plus an antibiogram, a probabilistic bi-antibiotic treatment with ceftriaxone $2 \mathrm{~g} / \mathrm{d}$ and metronidazole 500mg $3 / \mathrm{d}$ followed by a drainage incision $12 \mathrm{~h}$ later was instituted (Fig.1). At J2 hospitalization we noticed a modification of the skin color (blackish aspect) a chest extension, associated with a toxiinfectious table. (Fig. 2)

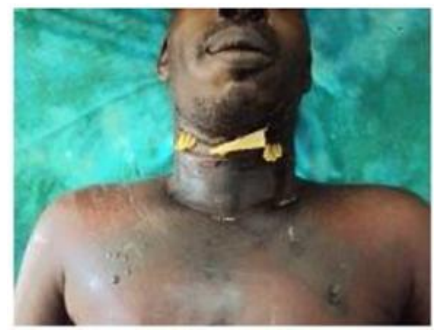

Fig1. Patient admitted to hospital after first Surgery

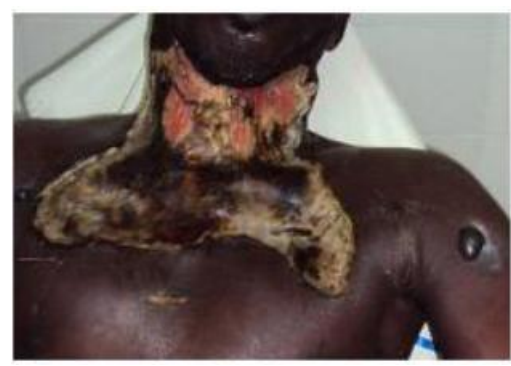

Fig2. Two days after hospitalization (modification of the color of the skin)

An operative indication was made and the following day we implemented a surgical exploration by a cervico-thoracic excision. A purulent fluid was found subcutaneously with respect of the aponeurotic plane (Fig. 3). Several washes were carried out with iodine polyvidone, saline and hydrogenated water. At J4 of hospitalization at postoperative J1 we noticed an aggravation of the toxic-infectious syndrome with rapid extension of the necrosis in the arms and the abdomen. In front of a picture we have a suspected FN and proceeded urgently to a broad surgical debridement which allowed us to see a necrosis of the subcutaneous tissue and the fascia as well as an important edema. On a thoracic and abdominal cleanser, a procedure for complete excision of the cutaneous and subcutaneous tissues respecting the musculoaponeurotic plane in cervical, brachial, thoracic and abdominal (Fig.4,5,6). The histology of the resection showed a diffuse gangrenous necrosis affecting the subcutaneous tissues and the fascia, thus confirming the diagnosis of NF. While the bacteriological examination carried out at the entrance made it possible to identify a streptococcus resisting to the ceftriaxone but sensitive to the amoxicillin-clavulanic acid combination. We therefore substituted the amoxicillin-clavulanic acid combination with ceftriaxone at the dosage of $1 \mathrm{~g} 3 / \mathrm{d}$. The local care consisted of tri-daily dressings at Dakin * and then after complete detersion after 3 days dressings directed to natural honey every 2 days were instituted. The evolution was favorable with a satisfactory budding after 2 weeks (Fig.7). The indication of a management of the loss of substance by a skin graft, but it could not be implemented for lack of financial means. The patient was seen again in the 4th month and had retractile scar flanges in the neck and armpits causing neck flexion and limitation of abduction movements of the arms (Fig.8). A second operative indication was made and we carried out under GA, debridement of retractile scars and a total skin graft (Figs.9,10). The operative sequences were favorable with good graft intake (Fig.11).

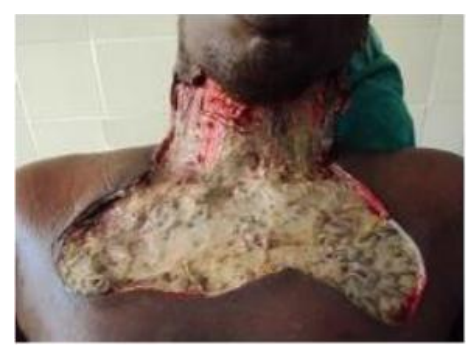

Fig3. Purulent fluid in subcutaneous

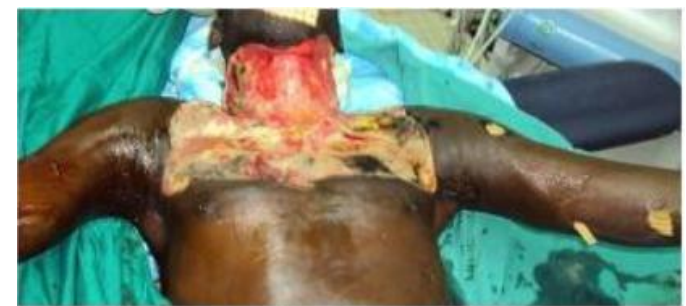

Fig4. Extension of necrosis to arm, thorax and abdomen 


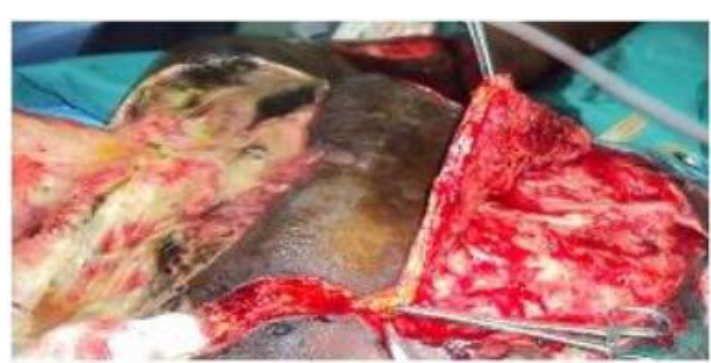

Fig5. During the surgery (Broad debridement)

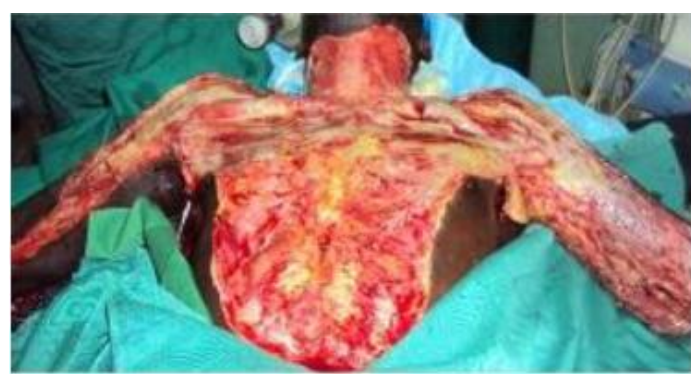

Fig6. Immediate post- operative aspect

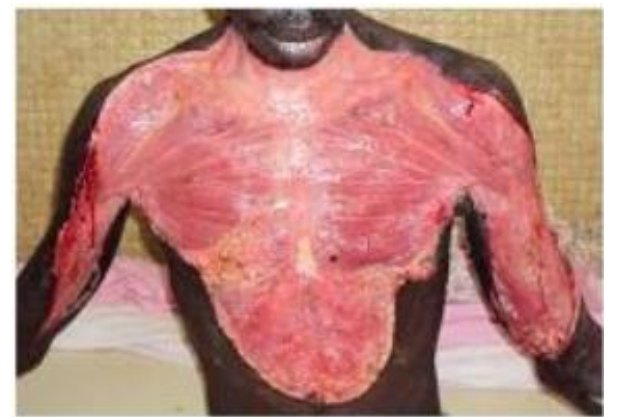

Fig7. Two weeks after surgery (good budding after natural honey dressings)

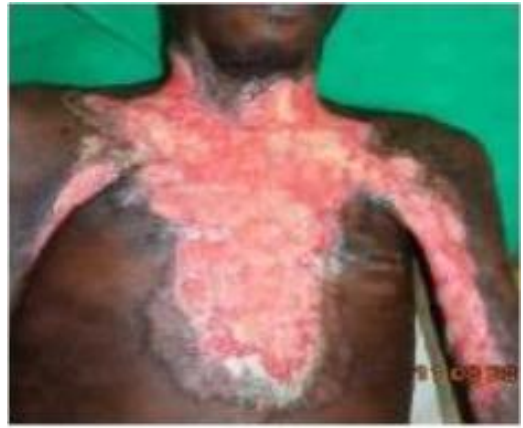

Fig8. Retractable scar flanges preventing neck extension

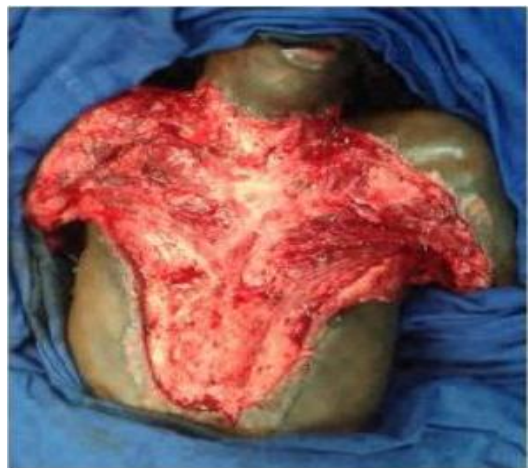

Fig9. Per-operative appearance after flange lifting

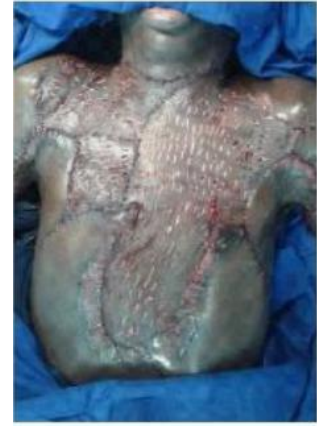

Fig10. Immediate Post-operative aspect

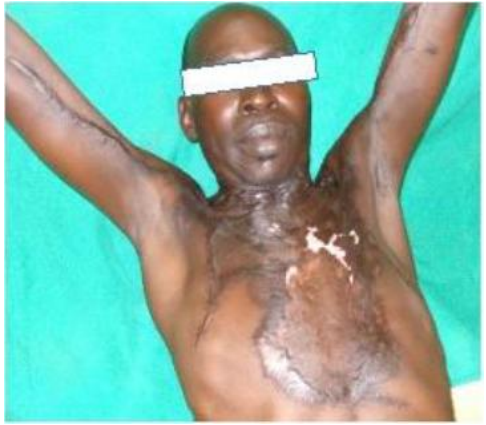

Fig11. Seven months after surgery (good graft intake)

\section{DISCUSSION}

$\mathrm{NF}$ is classified according to their bacterial etiology. There are 4 categories $[8,9]$ :

Type 1: fasciitis due to aero-anaerobic mixed flora,

Type 2: group A beta-hemolytic streptococcus fasciitis,

Type 3: clostridial perfringens-related cellulites, clostridia-related gas gangrene and nonclostridial cellulites related to aeroanerobic mixed flora,

Type 4:, post-surgical and slow progression Meleney gangrene, due to aureus staphylococcus and streptococcus.

It is a rare disease of rapid progression threatening the patient's life $[9,10,11]$. It accounts for about 2.5\% of head and neck infections [12]. It affects people of all ages with a peak in the fourth decade without distinction of sex and race $[13,14]$. It affects In the order of decreasing frequency the abdominal wall, perineum and limbs, its cervico-facial localization is rare to find $3-4 \%$ according to Arruda and al [15] and 2-3.6\% according to Hsiao and al (16). In this etiology location, the most frequently known is the periapical infection of a mandibular molar [6,17]. Rarely, pharyngeal infections, tonsillar and salivary gland infections, cervical adenitis, trauma and infections of the tumors of the otorhinolaryngeal 
sphere may be the cause [6, 9]. The most common germ is a Group A hemolytic beta streptococcus [18]

In our case, it was a male, 43-year-old black subject admitted for a necrotizing fasciitis with cervico-brachio-thoraco-abdominal localization following a caries of the 36 with the notion of self-medication based on monotherapy antiinflammatory. The germ found was an unspecified streptococcus .

Predisposition factors have been identified including: obesity, diabetes, chronic renal failure, age over 60 years, immunosuppressive drugs, malnutrition, peripheral arterial disease, cancer, chronic alcoholism. To these predisposing factors are added favoring or aggravating factors which are: trauma, surgery, minor invasive processes (acupuncture, aspiration ...), intravenous drug injections, insect bites, soft tissue infections, Burns and deliveries [19]

From a pathogenic point of view, the roots of the mandibular molars are located below the insertion of the mylo-hyoid muscle. Any periapical abscess in these teeth can pass through the lingual floor under the mylo-hyoid muscle to reach the under mandibular space. From there the infection will progress to the para-pharyngeal spaces and the space under the mandibular to reach the base of the skull (progression cephalic) or the base of the neck and the mediastinum (caudal progression) through the cervical fascia.(20). This infectious progression is favored by the relative hypovascularization of the cervical fasciae $[20,21]$.

Clinically, necrotizing fasciitis is often confused initially with acute cellulitis or an erysipelas. The first signs found are the pain and inflammatory oedema of the skin, there is a disproportion between the intensity of the pain and the inflammation [14,22]. Clinical evidences of suspicion have been identified:

Table1. Clinical features suggestive of necrotizing soft tissue infections [19,22]

\begin{tabular}{|l|lr|}
\hline SKIN & PAIN & GENERAL \\
\hline $\begin{array}{l}\text { Erythema with } \\
\text { ill-defined } \\
\text { margins }\end{array}$ & $\begin{array}{l}\text { Pain that } \\
\text { extends past } \\
\text { margin of } \\
\text { apparent } \\
\text { infection }\end{array}$ & $\begin{array}{l}\text { Fever with } \\
\text { toxic } \\
\text { appearance }\end{array}$ \\
\hline $\begin{array}{l}\text { Tense edema } \\
\text { with grayish or } \\
\text { brown discharge }\end{array}$ & $\begin{array}{l}\text { Severe pain } \\
\text { that appears } \\
\text { disproportioate } \\
\text { to physical }\end{array}$ & $\begin{array}{l}\text { Altered } \\
\text { mental state }\end{array}$ \\
\hline
\end{tabular}

ARC Journal of Dental Science

\begin{tabular}{|l|l|l|}
\hline $\begin{array}{l}\text { Lack of } \\
\text { lymphangitis or } \\
\text { lymphadenopathy }\end{array}$ & $\begin{array}{l}\text { Decreased pain } \\
\text { or anesthesia at } \\
\text { apparent site of } \\
\text { infection }\end{array}$ & Tachycardia \\
\hline $\begin{array}{l}\text { Vesicles or } \\
\text { bullae, } \\
\text { hemorrhagic } \\
\text { bullae }\end{array}$ & & $\begin{array}{l}\text { Tachypnea } \\
\text { due to } \\
\text { acidosis }\end{array}$ \\
\hline Necrosis & & $\begin{array}{l}\text { Presentation } \\
\text { with DKA } \\
\text { or HHNK }\end{array}$ \\
\hline Crepitus & & \\
\hline
\end{tabular}

Biology makes it possible to establish the LRINEC ( Laboratory risk indicator necrotizing fasciitis) score.

Table2. LRINEC score [19, 23, 24]

\begin{tabular}{|l|l|}
\hline INVESTIGATION & SCORE \\
\hline Serum C-reactive protein $\geq 150 \mathrm{mg} / \mathrm{L}$ & 4 points \\
\hline White bloodcell count & \\
\hline$\bullet \quad 15000 / \mu \mathrm{L}-25000 / \mu \mathrm{L}$ & 1 point \\
\hline$\bullet \quad>25000 / \mu \mathrm{L}$ & 2 points \\
\hline hemoglobin $11.0-13.5 \mathrm{~g} / \mathrm{dL}$ & 1 point \\
\hline$\bullet \quad<11 \mathrm{~g} / \mathrm{dL}$ & 2 points \\
\hline$\bullet \quad 2$ points \\
\hline Serum sodique $<135 \mathrm{mEq} / \mathrm{L}$ & 2 points \\
\hline $\begin{array}{l}\text { Serum creatinine }>1.6 \mathrm{mg} / \mathrm{dL}(141 \\
\text { mmol/L) }\end{array}$ & 1 point \\
\hline $\begin{array}{l}\text { Serum glucose }>180 \mathrm{mg} / \mathrm{dL}(10 \\
\mathrm{mmol} / \mathrm{L})\end{array}$ \\
\hline
\end{tabular}

A score of :

- $\leq 5$ points indicates a low risk $(<50 \%$ probability) of necrotizing fasciitis.

- 6-7 points indicate an intermediate risk (50 $\%-75 \%$ probability) of necrotizing fasciitis.

- 8 points or more indicate a high risk (> 75 $\%$ probability) of necrotizing fasciitis.

Medical imagery can be a contribution in case of doubt $[9,22,25]$ :

The standard radiography may reveal subcutaneous emphysema, this is a specific sign but its absence should not obscure a necrotizing fasciitis.

The scanner will reveal multiple subcutaneous fluid collections, the presence of collection of gas, myositis, mediastinal fluid, pleural and pericardial are other associated signs. Its sensitivity might be $80 \%$

IRM will visualize the edema infiltrating soft tissues and the lack of enhancement after administration of $\mathrm{T}$-weighted gadolinium signals a necrosis of the fascia. 
The diagnostic certainty will be given only on the histology of the operative part.

Necrotizing fasciitis is a real medico-surgical emergency shared by all the authors. The management of this sickness is multi disciplinary. As soon as the diagnosis is suspected, surgery is necessary.

This surgery is the last stage of diagnosis and the first stage of treatment. This is a mutilating surgery that will not worry about the aesthetic appearance. A broad debridement must be made that extends beyond the apparent limits of the necrosis zone. It is indicated in this context to make a first tracheotomy to prevent any asphyxic risk. We will also treat the cause, especially the causal tooth that will be extracted, because it is better to lose a tooth than to lose a life.

A broad spectrum probabilistic antibiotic therapy should be instituted taking into account the knowledge of the oropharyngeal microbial flora.

Multi-daily antiseptic dressings must be made.

Adjuvant treatments such as hyperbaric oxygen therapy and VAC therapy are necessary for the management of the surgical site.

In our patient after extensive cervico-brachiothoraco-abdominal debridement and extraction of 36 under antibiotic coverage, we have performed pluriquotodian antiseptic dressings. In the absence of oxygen therapy and VAC therapy, the operating site was taken care of natural honey dressings. The evolution was marked by retractile scars operated 4 months later with reparation of the loss of cutaneous substance. The postoperative were favorable.

\section{CONCLUSiON}

Necrotising fasciitis is a rare illness nowadays with the advent of antibiotics. It is therefore sometimes misunderstood even by specialists, often referring to the diagnosis of cellulitis or erysipelas. It is a true medical-surgical emergency quickly putting into play the vital prognosis in the absence of any adapted treatment. It must be suspected in front of any cutaneous necrosis associated with a toxiinfectious syndrome.

\section{REFERENCES}

[1] Wilson B. Necrotizing fasciitis. Am Surg. 1952; 18:416-31.

[2] Lingaraj JB, Sanjay Rao, Kotrashetti SM, Chintan Narad. Necrotizing cervical fasciitis: a case report and review of literature. J Maxillofac Oral Surg $2010 ; 9(1): 54-56$
[3] Travers T (1824). Two cases of slough ulceration. London Medical and Physical Journal.122-134

[4] Welbank R (1844). On sloughing phagedena. London: Longmans Brown and Green.

[5] Birnbaum DJ, D'Journo XB, Avaro JP, Trousse D, Giudicelli R, Fuentes P, Doddoli C, Casanova D, Thomas $\mathbf{P}$. Fasciite nécrosante de la paroi thoracique. ChirurgieThoraciqueCardiovasculaire2009; 13 : 49-52.

[6] Juncar M, Bran S, Juncar RI, Bacuit MF, Bacuit G, Onisor-Gligor F. Odontogenic cervical necrotizing fasciitis, etiological aspects. Niger J of ClinlPract 2016; 19: 391-6.

[7] Moon-Gi Choi. Necrotizing fasciitis of head and neck: a case report. J Korean Assoc Oral MaxillofacSurg 2015; 41: 90-96.

[8] Neelam V, Ajay K, Subhash P, Harsh K.Necrositing fasciitis of neck. Indian Journal of Otolaryngology and Head and neck Surgery Vol.54 No.2, April-June 2002.

[9] Ouazzani A, Dequanter D, Buttafuoco F, Raynal P, Lothaire P. Fasciite nécrosante cervicale compliquant un abcès dentaire: observation Clinique rare. Rev Med Brux 2009; 30: 99-105

[10] McHenry CR, Piotrowski JJ, Petrinic D, Malangoni MA. Determinants of mortality for necrotizing soft tissue infections. Ann Surg 1995; 221: 558-63.

[11] Sahli A, Chadli A, El Aziz S, Farouqi A. Necrotizing fasciitis in diabetic patients: A report of 14 cases. European Annals of Otorhinolaryngology Head and Neck Diseases 2015; 132 (4): 181-184

[12] Tung-Yu W, Jehn-Shyun H, Ching-Hung C, Hung-An C. Cervical necrotizing fasciitis of odontogenic origin: A report of 11 cases. J Oral MaxillofacSurg 2000; 58: 1347-52.

[13] Ericka K, Robert C, Cecile S. Pediatric Cervicofacial necrotizing fasciitis: A case report and review of a 10 years national pediatric database. Arch Otolaryngol Head Neck Surg. 2012 April; 138(4): 372-75.

[14] Vivek S, Antony J. Necrotizing fasciitis: An unusual presentation. Indian $\mathrm{J}$ Otolaryngol Head Neck Surg (October-December 2011) 63 (4): 390-92.

[15] Arruda JA, Figueiredo E, Alvares P, Silva L, Silva L, Caubi A, Silveira M, Sobral $P$. Cervical necrotizing fasciitis caused by dental extraction. Case Reports in Dentistry, Volume 2016, Article ID 1674153, 5 pages.

[16] Hsiao CT, Weng HH, Yuan YD, Chen CT, Chen JC. Predictors of mortality in patients with necrotizing fasciitis. Am J Emerg Med. 2008; 26 : 170-75 
[17] Umeda M, Minamikawa T, Komatsubara H, Shibuya Y, Yoko S, Komori T. Necrotizing fasciitis caused by dental infection: a retrospective analysis of 9 cases and a review of the literature. Oral Surg Oral Med Oral Pathol Oral RadiolEndod 2003; 95: 283-90.

[18] Fihman V, Raskine L, Petitpas F, Mateo J, Kania R, Gravisse J, Resche-Rigon M, Farhat I, Bercot B, Payen D, Sanson-Lepors MJ, Herman P, Mebazaa A. Cervical necrotizing fasciitis: 8-years' experience of microbiology. Eur J ClinMicrobiol Infect Dis 2008; 27: 691-95.

[19] Rukshini P, Jason CMH, Shanker P. Necrotizing fasciitis. Can Fam Physician 2009; 55: $981-7$

[20] Linder HH. The anatomy of the fasciae of the face and neck with particular reference to the spread and treatment of intraoral infections (Ludwig's) that have progessed into adjacent fascial spaces. Ann Surg December 1986; 204 (6); 705-14.
[21] Ledingham IM, Tehrani MA. Diagnosis, clinical course and treatment of acute dermal gangrene. Br J Surg 1975; 62: 364-72.

[22] Al Shukry S, Ommen J. Necrotizing fasciitis: report of ten cases and review of recents literature. Journal of Medicine and life 2013; 6 (2): 189-94

[23] Anaya DA, Dellinger EP. Necrotizing soft tissue infection diagnosis and management. Clin Infect Dis 2007; 44(5): 705-10 Epub 2007 jan 22.

[24] Wong CH, Khin W, Heng KS, Tan KC, Low CO. The LRINEC (laboratory risk indicator of necrotizing fasciitis) score: a tool for distinguishing necrotizing fasciitis from other soft tissue infections. Crit Care Med 2004; 32(7): 1535-41.

[25] Wessam BA, Jason M, Suresh M. Computed tomography imaging of acute inflammatory process. World J Radiol 2010 March 28; 2(3): 91-96.

Citation: Koffi KM, Ory DMAO, Ouattara B, Harding-Kaba MB, Moudalbaye NS, Daweni D et al. CervicoBrachio-Thoraco-Abdominal Necrotizing Fasciitis of Dental Origin: A Clinical Case. ARC Journal of Dental science. 2017; 2(2):4-9. doi:dx.doi.org/10.20431/2456-0030.0202002.

Copyright: (C) 2017 Authors. This is an open-access article distributed under the terms of the Creative Commons Attribution License, which permits unrestricted use, distribution, and reproduction in any medium, provided the original author and source are credited. 